\title{
MENINGKATKAN KEPEDULIAN PENDIDIKAN MASYARAKAT MELALUI PROGRAM KOMUNITAS SEBERSY (Sekolah Bersama Yuk)
}

\author{
Rheenda Kumala, Fajar Maulidi Rahmani, Yessie Ayu Yulianti, Feri Apriandi. \\ rheendakumalaa2@gmail.com \\ Mahasiswa Fakultas Agama Islam
}

\begin{abstract}
ABSTRAK
Judul PKM-M ini adalah Meningkatkan Kepedulian Pendidikan Di Masyarakat Kampung Ceger Melalui Program Sebersy ( Sekolah Bersama Yuk ) di Kampung Ceger di pinggir Kota Bogor. Latar belakang masalah untuk mengadakan kegiatan pengabdian ini berawal dari keprihatinan kami akan kurangnya kesadaran masyarakat akan pentingnya pendidikan dikarenakan faktor ekonomi dan lain sebagainya terkhusus di Kampung Ceger. Sasaran dari kegiatan ini adalah anak anak Kampung Ceger yang putus sekolah dan membutuhkan perhatian khusus dalam bidang pendidikan dikarenakan kondisi ekonomi orangtua mereka yang kurang berkecukupan untuk melanjutkan sekolah anak-anaknya setelah sekolah dasar. Letak wilayah yang hampir dekat dengan kota belum menjamin mutu pendidikan mereka. Untuk mengatasi masalah tersebut kami bekerjasama dengan Sekolah Bersama Yuk untuk melaksanakan program yang juga telah terealisasi oleh Sebersy. Luaran dari kegiatan PKM-M ini berupa fasilitas Rumah Belajar yang lebih layak untuk anak-anak Kampung Ceger dan publikasi ilmiah berupa artikel.
\end{abstract}

Kata Kunci: Anak-anak Kampung Ceger, Pendidikan, Sebersy.

\section{PENDAHULUAN}

\section{Latar Belakang}

Pendidikan merupakan hal terpenting dalam kehidupan suatu individu karena dengan berpendidikan seseorang dapat mendapatkan kehidupan yang jauh lebih baik. Pendidikan melatih manusia untuk memiliki tingkat penyesuaian diri yang baik dalam berinteraksi dengan lingkungan, dengan sesama manusia maupun lingkungan alam. Untuk itu pendidikan pada satu individu harus ditanamkan sejak dini sampai ia dewasa bahkan sampai akhir hayatnya.

Berawal dari rasa prihatin seorang pendiri Sebersy di salah satu satu kampung dipinggir kota Bogor yang masyarakatnya masih kurang peduli akan pendidikan anak-anaknya. Mereka yang mayoritas bekerja sebagai buruh bangunan, pedagang dan lain sebagainya masih menganggap bahwa pendidikan bukanlah hal yang begitu penting. Tim kami disini ingin berusaha meningkatkan pendidikan disalah satu kampung dipnggiran Kota Bogor ini denga bekerja sama dengan Sebersy (Sekolah Bersama Yuk) untuk lebih mensejahterakan masyarakatnya.

Sekolah Bersama Yuk atau disingkat Sebersy merupakan sebuah komunitas yang bergerak di bidang pendidikan anakanak kurang mampu yang berada di wilayah kota dan Kabupaten Bogor. Awal didirikannya komunitas ini bermula dari Bima Prasetyo Adi (pendiri Sebersy) yang melihat fenomena sekelompok anak-anak "bekerja" sebagai pemulung dan pengemis pada waktu malam di sekitar Jalan Bangbarung, Kota Bogor. Merasa penasaran, Bima pun bertanya pada kelompok anak-anak tersebut mengenai alasan mengapa mereka sampai harus melakukan kegiatan seperti itu di usia yang masih sangat muda. Bima pun mendapat 
jawaban yang sangat polos dari anak-anak tersebut. Mereka melakukan hal seperti itu semata untuk membeli peralatan dan seragam sekolah.Merasa harus melakukan sesuatu, dengan modal keberanian, Bima menjanjikan kepada aak-anak tersebut akan mengadakan sebuah kelompok belajar yang diikuti oleh 10 orang anak yang hidup di jalanan. Karena Sebersy memiliki visi misi bahwa pendidikan tidak hanya melahirkan cendikiawan melainkan kualitas akal budi dan kejujuran.

\section{Potret, Profil, Dan Kondisi Khalayak Sasaran}

Sebagian besar masyarakat Kampung Ceger bekerja sebagai buruh, pedagang, pegawai bangunan, asisten rumah tangga dan lain sebagainya. Sebagian besar anakanak mereka hanya melanjutkan sekolah sampai tingkat SD atau SMP. Kepedulian mereka terhadap pendidikan masih sangat minim dikarenakan kurangnya pengetahuan para orangtua dan kurangnya kesadaran akan pentingnya pendidikan. Beruntungnya, pimpinan RT sangat mendukung adanya program yang dijalankan oleh Sekolah Bersama Yuk sebagai mediator untuk mendidik anakanak di Kampung tersebut.

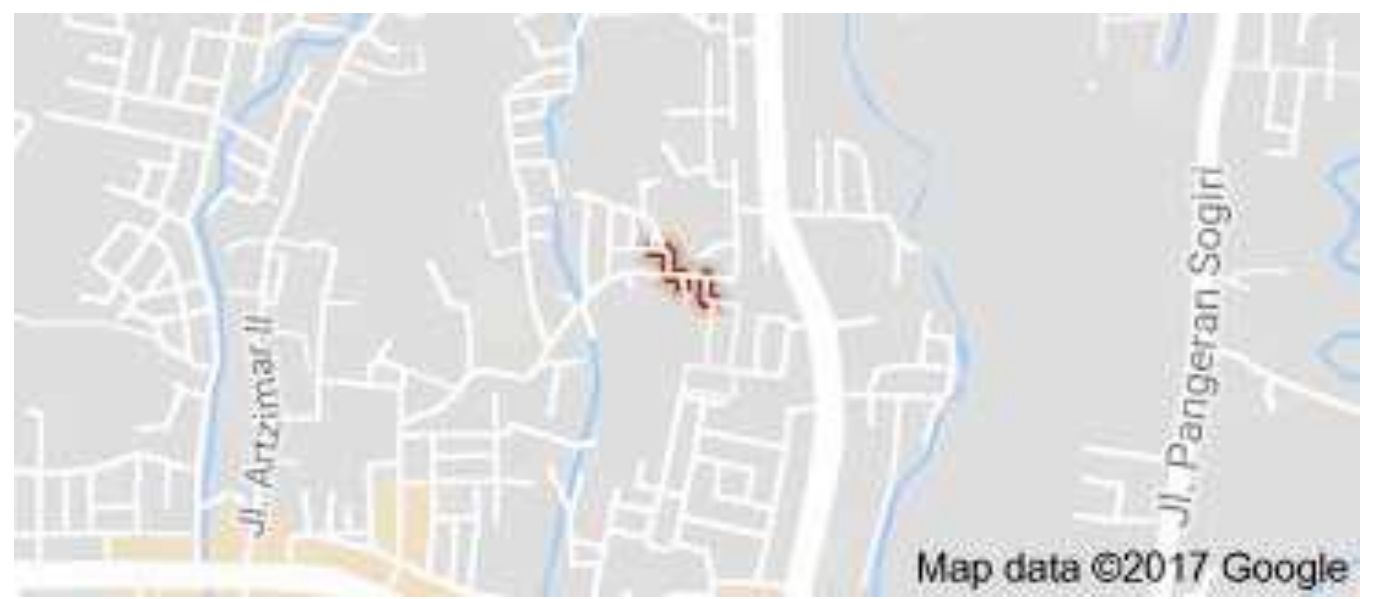

Lokasi Kampung Ceger

Kondisi Dan Potensi Wilayah Dari Segi Fisik Sosial Ekonomi Maupun Lingkungan Yang Relevan Dengan Kegiatan Yang Akan Dilakukan

Potensi dari segi fisik sosial ekonomi dari wilayah tersebut masih belum bisa dikatakan sejahtera karena mayoritas dari mereka masih bekerja sebagai buruh dan sebagai asisten rumah tangga. Mereka bekerja untuk menafkahi keluarganya dan masih kekurangan sehingga tidak ada biaya untuk menyekolahkan anak-anaknya samapi ke jenjang selanjutnya setelah sekolah dasar.

\section{Kondisi Masyarakat Sasaran Yang Akan Menerima Kegiatan}

Sekitar Kampung ceger merupakan wilayah dengan suasana pinggir kota, bahkan dekat dengan perumahan pusat kota, namun jika ditelusuri lebih lanjut, akan ada suatu pemukiman sempit diujung lokasi yang merupakan salah satu pemukiman padat penduduk. Walau dengan lokasi yang dekat dengan kota, kondisi masyarakat sangatlah tidak mempedulikan pendidikan dan tidak sedikit pula anak-anak setempat tak mendapatkan pendidikan yang layak karena keadaan ekonomi orang tua mereka. 


\section{Permasalahan Yang Dihadapi Masyarakat}

Dilatarbelakangi oleh kondisi orangtua mereka yang tidak mengenyam pendidikan yang tinggi menjadikan mereka terperangkap dalam zona yang tidak seharusnya mereka rasakan dan menganggap bahwa pendidikan itu adalah hal yang tidak begitu penting untuk di

\section{METODE PENELITIAN}

\section{Tahap Persiapan Pelaksanaan}

Pelaksanaan program ini akan dilakukan dalam beberapa tahapan yaitu : Tahap pertama Kami akan melakukan sosialisasi program yang akan kami laksanakan kepada para masyarakat Kampung Ceger dan anggota Sebersy sehingga terbentuk kerjasama yang solid. Tahap ke dua kami akan memberikan penyuluhan dan penjelasan secara teori tentang cara metode pembelajaran anakanak usia dini. Tahap ketiga kami akan melakukan pendahuluan dengan memperkenalkan metode pembelajaran yang kreatif dan inovatif seperti program yang sudah terlaksana oleh pihak Sebersy. Seperti ;

1 Kelas Kuliner; memasak, mengetahui nutrisi yang terkandung dalam beberapa makanan, pengetahuan macam-macam makanan khas daerah

2 Kelas Edutainment; mengadopsi nilainilai positif dari intertainment arau berita-berita elektronik lainnya

3 Kelas English Club; speaking, grammar

4 Kelas Agama; baca tulis al-qur'an, kaligrafi dan pengenalan sejarah Islam. dapatkan. Melalui Sebersy ini akan menampung anak-anak kampung ceger agar terciptanya masyrakat yang lebih sejahtera dalam bidang pendidikannya. Dengan adanya program ini dapat membantu pendidikan mereka karena kami disini untuk mengajarkan hal-hal yang belum mereka ketahui terutama anak-anak.

\section{Pelaksanaan}

Bekerjasama dengan Sebersy, dan menyesuaikan dengan visi-misi yang dimiliki oleh pihak Sebersy kami akan melaksanakan kegiatan belajar mengajar di salah satu tempat yang ada di kampung ceger, di program ini juga akan di adakan sebuah permainan yang dapat membuat mereka termotivasi belajar dan kami juga akan menyediakan rewards untuk mereka yang dapat memenangkan permainan berupa nilai yang akan di berikan untuk mereka. Permainan ini akan meningkatkan semangat serta kreativitas anak anak dalam pembelajaran.

\section{Evaluasi}

1 Mengevaluasi apakah cara tersebut dapat meningkatkan kepedulian minat belajar anak-anak di Kampung Ceger agar menjadi lebih baik lagi dan bermanfaat untuk keberhasilan hidup mereka, kita juga perlu memberikan suatu wawasan yang baik dan berguna untuk mereka dengan memotivasi minat belajar dengan metode yang menarik dan tidak membosankan.

2 Evaluasi kegiatan ini akan dilaksanakan secara komprehensif, merefleksi setiap kegiatan apakah berjalan dengan baik dan apa kendala atau hambatan serta tindak lanjut yang akan dilaksanakan. 


\section{BIAYA DAN JADWAL KEGIATAN}

Format Ringkasan Anggaran Biaya PKM-M

\begin{tabular}{|l|l|l|}
\hline No & Jenis Pengeluaran & Biaya (Rp) \\
\hline 1. & Penunjang & Rp. $2.000 .000,-$ \\
\hline 2. & Bahan habis pakai & Rp. 3.000.000,- \\
\hline 3 & Perjalanan & Rp. 2.500.000,- \\
\hline 4 & Lain-lain: Administrasi,publikasi,seminar,laporan & Rp. 2.000.000,- \\
\hline & Jumlah & Rp. 9.000.000,- \\
\hline
\end{tabular}

\begin{tabular}{|l|l|l|l|l|l|l|}
\hline \multirow{2}{*}{ No } & \multirow{2}{*}{ Jenis Kegiatan } & \multicolumn{5}{|c|}{ Bulan } \\
\cline { 3 - 6 } & & $\mathbf{1}$ & $\mathbf{2}$ & $\mathbf{3}$ & $\mathbf{4}$ & $\mathbf{5}$ \\
\hline 1 & $\begin{array}{l}\text { Persiapan perangkat } \\
\text { pengabdian }\end{array}$ & & & & & \\
\hline 2 & Pelaksanaan Program & & & & & \\
\hline 3 & Pelaksanaan Program & & & & & \\
\hline 4 & $\begin{array}{l}\text { Evaluasi dan } \\
\text { Laporan }\end{array}$ & & & & & \\
\hline 5 & $\begin{array}{l}\text { Publikasi/artikel } \\
\text { ilmiah/seminar }\end{array}$ & & & & & \\
\hline
\end{tabular}




\section{KESIMPULAN}

\section{Tujuan Khusus}

Berdasarkan rumusan masalah di atas, maka penelitian ini bertujuan khusus untuk:

1 Untuk menguji efektivitas penggunaan media aplikatif pada pembelajaran aksara Rejang "Ka Ga Nga”Untuk mengetahui huruf aksara ka ga nga

2 Untuk upaya pelestarian kearifan lokal aksara dari Suku Rejang di Kabupaten Bengkulu

\section{Urgensi (Keutamaan Penelitian)}

Keutamaan atau urgensi dari penelitian ini adalah diharapkan ditemukannya pengembangan untuk pelastarian aksara "Ka Ga Nga" agar mencegah terjadinya kepunahan. Meningkatkan antusias belajar siswa melalui media aplikatif dalam pembelajaran aksara "Ka Ga Nga". Temuan yang ditargetkan pada penelitian ini yaitu modia pembelajaran aplikatif untuk meningkatkan kecintaan siswa terhadap aksara Rejang.

\section{Luaran yang diharapkan}

Target luaran dari Program ini adalah:

1 Sebagai wadah mengembangkan Potensi dan Keterampilan Kampung Ceger.
2 Anak-anak Kampung Ceger mampu mendapatkan Pendidikan yang lebih baik lagi sesuai dengan program yang akan kami laksanakan.

3 Memotivasi Anak-anak untuk tetap melanjutkan pendidikan.

4 Mewujudkan Fasilitas rumah belajar yang lebih layak untuk kegiatan belajar mengajar, tempat berkumpul, serta memngembangkan bakat dan kreatifitas anak.

\section{Manfaat Pengabdian}

Manfaat pengabdian antara lain :

1 Meningkatkan kepedulian bagi masyarakat agar terciptanya minat belajar

2 Mengembangkan kreativitas dan kemampuan bersosialisasi anak-anak kampung Ceger

3 Sebagai upaya edukasi bagi masyarakat setempat agar meminimaliskan angka kemisikinan di wilayah tersebut untuk masa yang akan datang.

4 Membantu dan mendukung upaya pemerintah dalam menekan angka ketidakpedulian akan pendidikan khususnya pada daerah kampung ceger tersebut. 